\title{
Global trends in motor vehicle pollution control: a 2011 update Part 3
}

\section{Stringent vehicle emissions standards}

As summarized above, technologies are now in the market place or rapidly emerging which in combination with the clean fuels also discussed can lower road vehicle emissions of $\mathrm{CO}, \mathrm{HC}, \mathrm{NO}_{x}$, and $\mathrm{PM}$ and other toxins to a very small fraction of those from uncontrolled vehicles per kilometer driven and the major challenge now is to get these technologies adopted around the world.

The three dominant regulatory programs in the world are the US (including California), the European Union (EU), and Japan. The European and US standards and test procedures or some mixture of them have been adopted by many other countries. For example, China and India have adopted the EU standards for most vehicle categories, although lagging several years behind the EU for implementation.

It is important to emphasize two important points:

1. Standards adopted by the US and the EU will determine the types of technologies and pollution controls used on most light and heavy-duty vehicles around the entire world, so it is important that their standards are sufficiently stringent to address the environmental problems for which they are designed $^{1)}$, and

2. While the time gap is narrowing, most developing countries lag the US and the EU by 5 or more years in implementing the standards. Some countries including most of Africa have not yet started or have barely started on the road toward cleaner vehicles and fuels with the notable exception of the nearly universal phase out of leaded gasoline.

The EU and US light duty vehicle standards for $\mathrm{NO}_{\mathrm{x}}$ and PM emissions are summarized in Figure $7^{2)}$. While the test procedures used to determine compliance differ somewhat, the control technologies used are very similar and by 2015

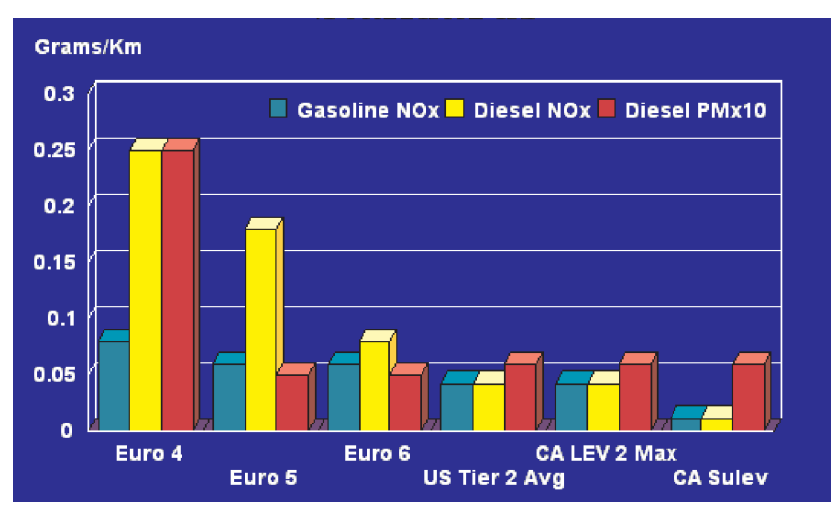

Fig. 7. EU and US light duty gasoline and diesel vehicle standards

\footnotetext{
1) No other country is following the Japanese vehicle standards roadmap. 2) The term $P M \times 10$ means that PM emissions are multiplied by ten.
}

when the Euro 6 standards are implemented will be almost identical.

With regard to heavy-duty vehicles and engines, the US has introduced the most stringent $\mathrm{NO}_{\mathrm{x}}$ and $\mathrm{PM}$ requirements to date. In the case of Japan, the requirements include a mandatory $\mathrm{NO}_{\mathrm{x}}$ requirement as well as a so-called challenging value which is only $1 / 3$ the mandatory requirement. If the challenging value is mandated (which is expected in several years), the Japanese requirements will be very similar to the US 2010 standards.

With regard to Euro VI heavy-duty requirements, the European Commission issued a proposal in December 2007, which it intended to be approximately equivalent to the US 2010 limits (see Fig. 8). In December 2008, the European Parliament voted overwhelmingly in favor of the new emissions curbs. The new Euro VI regulation will have direct effect and will not require transposition into national law by the 27 EU states.

The limit values cap emissions of nitrogen oxides at 400 milligrams per kilowatt-hour $(\mathrm{mg} / \mathrm{kW} \cdot \mathrm{h})$ and particulate matter at $10 \mathrm{mg} / \mathrm{kW} \cdot \mathrm{h}$. All new vehicles of existing models will have to demonstrate compliance with the limits from 1 January 2014 to obtain market approval. This is nine months earlier than proposed by the European commission. New models will have to meet the standards from 1 January 2013, three months earlier than the commission proposed.

Many countries and cities throughout Asia have much higher proportions of two and three wheeled vehicles than anywhere else in the world. This vehicle segment is also growing rapidly in cities such as Sao Paulo in Brazil. New two stroke engines are rapidly being phased out around the world).

In 2006, the European Union introduced Euro III standards for motorcycles (see Table 6) which are approximately equivalent to new car standards that applied in the EU in 2000 , and these requirements have received a great deal

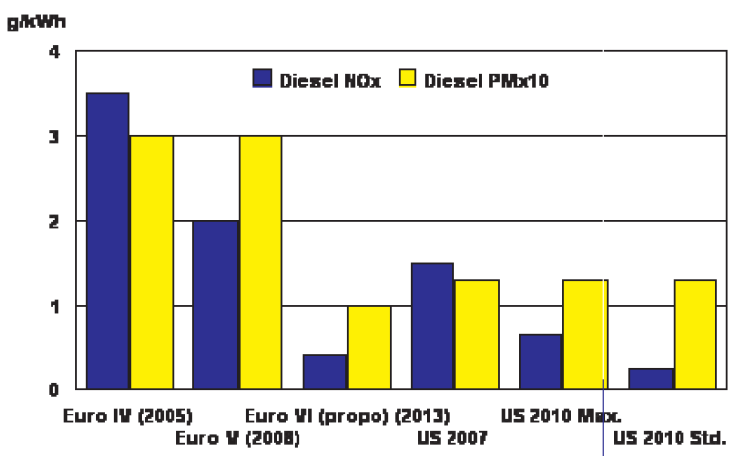

Fig. 8. U.S. versus Europe Heavy Duty Transient Cycle emissions standards 
of attention from countries around the world. Both Taiwan (2007) and China (2008) have adopted the EU requirements with only slight variations.

Table 6. Euro III motorcycle standards (2006)

\begin{tabular}{|c|c|c|c|}
\hline $\mathrm{HC}[\mathrm{g} / \mathrm{km}]$ & $\mathrm{NO}_{\mathrm{x}}[\mathrm{g} / \mathrm{km}]$ & $\mathrm{CO}[\mathrm{g} / \mathrm{km}]$ & Durability $[\mathrm{km}]$ \\
\hline 0.8 & 0.15 & 2.0 & 30.000 \\
\hline
\end{tabular}

The current status of emissions requirements for light duty vehicles, heavy duty vehicles and motorcycles is summarized below.
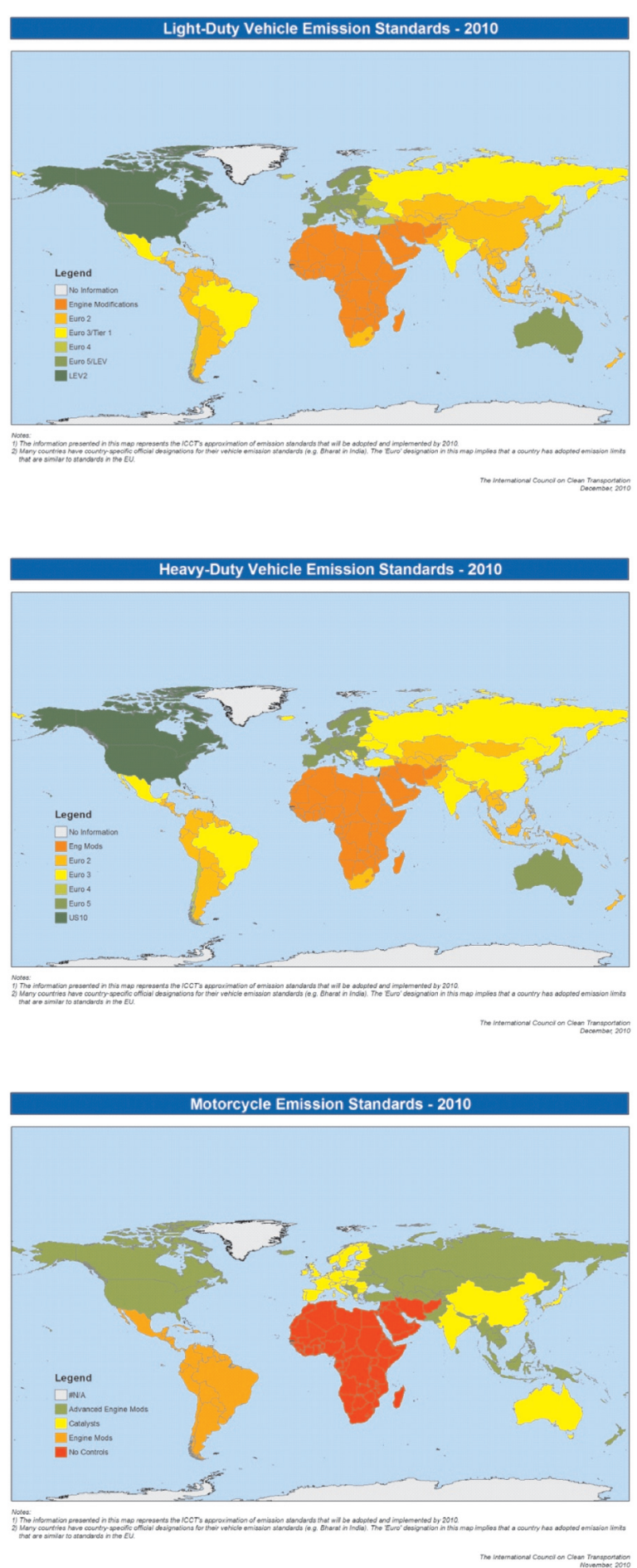

For light duty vehicles, substantial progress is occurring in the rapidly industrializing countries such as China, India and Brazil. Further, major cities such as Beijing in China and the major capitals such as Delhi in India are moving even more rapidly than the country as a whole. Beijing for example is already at standards for vehicles and fuels that are roughly equivalent to so called Euro 4 limits which went into effect in the European Union in 2005 and the city is expected to move to Euro 5 equivalent limits in 2012.

Africa (with the exception of South Africa) and the Middle East (with the exception of Israel) lack standards for new vehicles. Fortunately both of these regions are almost entirely using lead free gasoline so the potential to introduce catalyst based standards for new cars is high. Ironically, during a recent visit to a new car dealership in Nairobi, one noted that all the used cars on the lot, mainly imported from Japan were equipped with catalytic converters whereas none of the new cars had catalysts because none were required.

The picture is similar for heavy duty trucks and buses. However, even though tighter limits apply in some of the major cities, most heavy duty vehicles (with the exception of urban transit buses) are able to register and fuel outside the cities thereby being only required to meet the more lenient national standards.

With regard to motorcycles and scooters, catalyst based standards now dominate in the major markets of China and India and the production and sale of very dirty two stroke engines is gradually disappearing. However, even in Latin America where motorcycle sales are booming, new vehicle standards remain weak.

\section{Progress regarding transportation and global climate change}

With regard to GHGs the prognosis is less promising. As illustrated earlier in Fig. 5 (see PTNSS-SS2-212, page 114), $\mathrm{CO}_{2}$ emissions from the transportation sector grew significantly in recent decades. Because of the urgency of the problem, there is tremendous focus on reducing GHGs from the transportation and other sectors. In fact, this is generally now receiving greater emphasis than control of "conventional pollutants" and will likely have a greater impact on the development of vehicle technologies in coming years than traditional emissions standards.

\section{Strategies to reduce greenhouse gases and air pollution}

There are three basic technology-based approaches to reducing GHGs in the transportation sector:

- Setting mandatory or voluntary greenhouse emissions or fuel efficiency standards;

- Shifting to lower-carbon fuels and advanced vehicle technologies; and

- Reducing the use of motorized vehicles.

While the latter approach is critical and will likely be a necessary element of a successful approach it will not be discussed further as it is beyond the scope of this paper. 


\section{A. Vehicle standards}

A wide variety of technologies exist and more are emerging which can reduce fuel consumption and carbon dioxide emissions from road vehicles. These include variable valve timing, cylinder deactivation, gasoline direct injection, turbocharging and engine downsizing and increased dieselization. The State of California was the first to mandated greenhouse gas emissions standards [11]. At a US national level, mandatory Corporate Average Fuel Economy (CAFÉ) requirements have been in place since the mid 1970's but there has been no significant tightening in over 20 years until Congress mandated further control in 2007; these requirements will result in lower carbon dioxide emissions but do not address the other greenhouse emissions. The European Union on the other hand negotiated a voluntary agreement with the European vehicle industry to achieve carbon dioxide targets ${ }^{3)}$. This agreement broke down in early 2007 as it became clear that the target of 140 grams/kilometer by 2008 will not be met. As a result, the EU will impose a mandatory limit of 130 grams/kilometer to be phased in between 2012 and 2015 and will likely further tighten limits to 95 grams/kilometer in approximately 2020.

Japan's approach has also focused on fuel consumption using the best in class at a point in time to stimulate industry wide progress. A summary of planned or adopted vehicle requirements is shown in Fig. 9 [11].

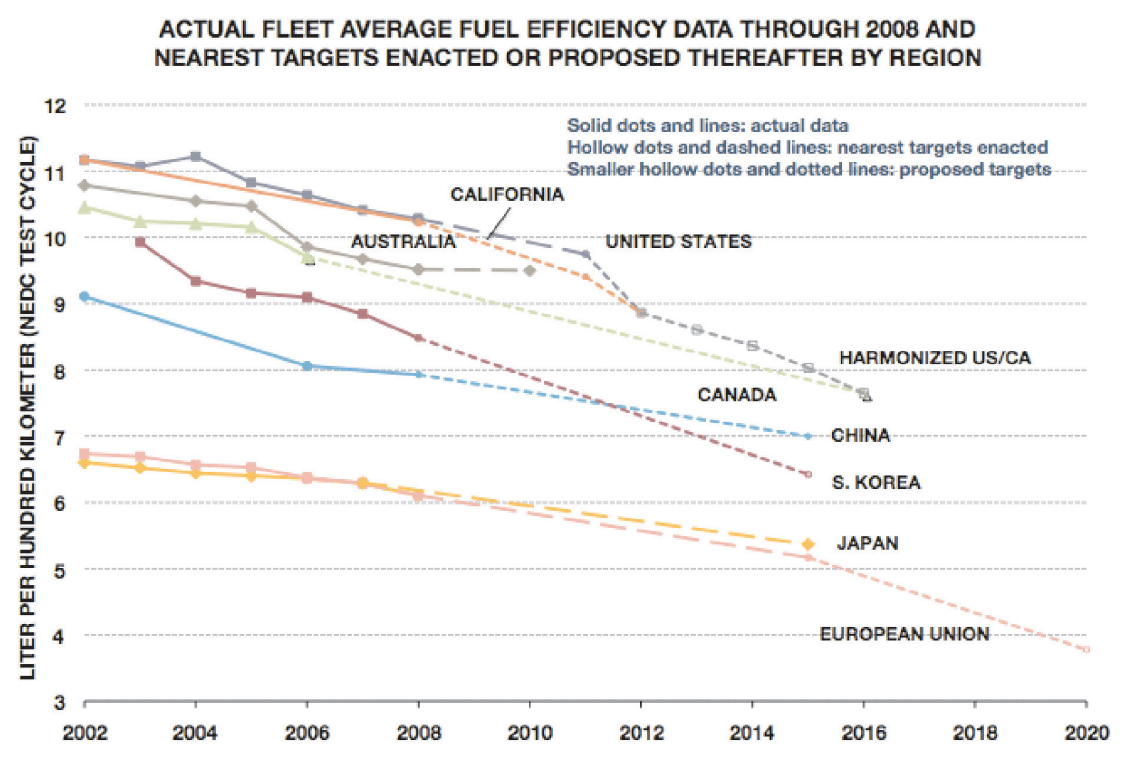

Fig. 9. Projected GHG emissions for new passenger vehicles by country/region

\section{B. Low carbon fuels}

Brazil was the first country to make a significant shift to renewable, lower carbon fuels based on producing ethanol from sugar cane but many countries around the world are now pursuing similar approaches with mixed success. California recently proposed carbon based fuels requirements and the

\footnotetext{
3) Similar agreements were also reached with the Japanese and Korean manufacturers.
}

EU is pursuing low carbon fuels standards (LCFS) [8]. However, to achieve significant global benefits from low carbon fuels it is increasingly clear that a full life cycle analysis ${ }^{4}$ is necessary which includes consideration of indirect land use effects. When such factors are taken into account, it is clear that moving to low carbon fuels that actually achieve significant benefits is a very difficult proposition.

The goal of a LCFS is to promote investment and use of low carbon fuels (e.g., sustainable corn ethanol and biodiesel, CNG, renewable electrons s. $^{5}$ hydrogen) and dampen demand for high carbon fuels (e.g. Canadian tar sands, Venezuelan shale oil, U.S. coal to liquids).

The current US renewable fuels standard (RFS), mandated by the Energy Independence and Security Act of 2007, takes a step toward a LCFS by requiring life-cycle GHG standards for 3 categories of biofuels: baseline renewable biofuels $20 \%$ below gasoline, advanced biofuels $50 \%$ improvement, and cellulosic biofuels $60 \%$ improvement. The RFS however only applies to biofuels and thus does not dampen demand for high carbon fuels (e.g., tar sands, coal to liquids).

California air regulators have adopted a mandate requiring low-carbon fuels, part of the state's wider effort to reduce greenhouse gas emissions. The California Air Resources Board voted 9-1 to approve the standards, which are expected to serve as a template for a national policy. The rules call for reducing the carbon content of fuels sold in the state by 10 percent by 2020 , a plan that includes counting all the emissions required to deliver gasoline and diesel to California consumers' from drilling a new oil well or planting corn to transporting it to gas stations.

The measure also sets the stage for emerging alternative fuels - such as cars that run on compressed natural gas and electric vehicles like plug-in hybrids that run on both gasoline and rechargeable batteries - to compete with second-generation ethanol. That fuel, cellulosic ethanol, is expected to be made in commercial amounts from non-food feedstocks like switch grass and fast-growing trees.

To give fuel producers time to adjust, the bulk of the carbon limits required under the regulation do not go into effect until 2015.

\footnotetext{
4) A full life cycle analysis is an effort to capture all the emissions associated with a given fuel from its extraction or harvest to refinement and transport all the way to the eventual consumption in the vehicle. Only in this way can a fair comparison be made between various fuels and can a fair accounting be made of their impact on climate change.

${ }^{5}$ If a significant portion of the vehicle fleet becomes battery electric or plug in hybrids, it will be important to produce the electricity for these vehicles using clean, renewable fuels. Otherwise the environmental benefits, especially with regard to climate impacts, will be greatly diminished.
} 


\begin{tabular}{|c|c|c|}
\hline Fuel type & Carbon intensity & $\begin{array}{l}\text { Carbon intensity (inclu- } \\
\text { ding landuse changes) }\end{array}$ \\
\hline California gasoline $\{+1\}$ & 95.85 & 95.85 \\
\hline Midwest ethanol $\{+2\}$ & 75.10 & 105.10 \\
\hline California ethanol $\{+3\}$ & 50.70 & 80.70 \\
\hline Brazilian ethanol $\{+4\}$ & 27.40 & 73.40 \\
\hline Landfill gas (bio-methane) $\{+5\}$ & 11.26 & 11.26 \\
\hline \multicolumn{3}{|c|}{$\begin{array}{l}\{+1\} \text { with } 10 \% \text { ethanol } \\
\{+2\} \text { with some of the plant's power coming from coal } \\
\{+3\} \text { with the plant's power coming form natural gas } \\
\{+4\} \text { made from sugarcane and shipped here } \\
\{+5\} \text { derived from landfills in California }\end{array}$} \\
\hline
\end{tabular}

- How much of the recent increase in the world price of corn and other grains is attributable to biofuels mandates in the U.S. and elsewhere?

- What are the prospects of plug-in hybrids and the ability of electric utilities to supply sufficient renewable electrons for this new market?

\section{Advanced vehicle technologies}

Looking longer term, with the anticipated continued growth in the vehicle population in major cities in developing countries and

California's regulators ranked 11 different ways of making corn ethanol. They found that traditional distilling methods used in the Midwest, accounting for the bulk of US supplies, emit the most carbon over a lifecycle measured from production to combustion. The state gave much better carbon savings scores to corn ethanol made in California with a distillery fired by a blend of natural gas and crop waste, also known as biomass.

The regulation rates different fuels based on their carbon intensity, measured as the number of grams of carbon dioxide released for every megajoule of energy produced. When the indirect land-use effects of biofuels are included, some types of ethanol rate worse than gasoline.

\section{Source: California Air Resources Board}

Electric utilities may opt into the program and generate credits if they sell renewable electrons to plug-in hybrids or all-electric vehicles. GHG emissions from direct and indirect land use changes are included in the estimation of fuel lifecycle GHG impacts.

The European Union adopted a LCFS similar to California. The new law will require fuel suppliers to cut life-cycle greenhouse gas emissions from road fuels by six per cent over the decade from 2010 to 2020 (intermediate targets: $2 \%$ by 31 December 2014 and 4\% by 31 December 2017). The cuts will come from production efficiency improvements and switches to cleaner fuels such as biofuels. Biofuels sustainability criteria will be added to the new law once they have been agreed in separate negotiations on a new renewable energy directive.

With this the EU has sent a clear signal that its market is not opened to carbon intensive marginal oils, such as tar sands or coal-to-liquid.

Several key technical and economic questions remain with regard to low carbon fuels, including:

- Significant uncertainty around lifecycle GHG emissions from U.S. corn ethanol (range is between average 25\% improvement over gasoline to twice the lifecycle GHG emissions of gasoline - thus making corn ethanol worse than tar sands and coal to liquids).

- If biomass for fuels can only be produced sustainably if grown on degraded land or produced from waste products (e.g., corn stover, forest wood waste), then what are the practical limitations of global supplies of sustainable biofuels? problems, it seems that a transition to advanced vehicle technologies including battery electric cars, hybrids, plug in hybrids and fuel cells will be necessary both to eliminate urban air pollution and to reduce transportation's impact on climate.

As noted earlier, battery, fuel cell and vehicle manufacturers are working vigorously to improve performance on a variety of fronts. For battery vehicles, the primary technical challenges involve safety, reliability/manufacturability, durability, and cost [3]. For fuel cell vehicles, the focus is on durability and cost [2], as well as providing hydrogen fuel in a cost-effective manner. All of these challenges are important and difficult.

A number of recent developments and announced goals suggest that the auto industry is moving down the cost curve and making more progress than was believed possible even a few years ago:

- Press reports stated that Toyota has cut the cost of making fuel-cell vehicles by about 90 percent since earlier estimates in the mid-2000s [17]. The Japanese carmaker has cut production costs to about one-tenth of earlier estimates that ran as high as $\$ 1$ million a car, and states that it would need to further reduce current expenses by about half before starting retail sales.

- In September 2009 Daimler, Ford, GM, Honda, Hyundai/ Kia, Toyota and the Renault-Nissan Alliance issued a joint Letter of Understanding stating in part "Based on current knowledge and subject to a variety of prerequisites and conditions, the signing OEMs strongly anticipate that from 2015 onwards a quite significant number of fuel cell vehicles could be commercialized. This number is aimed at a few hundred thousand $(100,000)$ units over life cycle on a worldwide basis. All OEMs involved will implement their own specific production and commercial strategies and timelines, and, as a consequence, depending on various influencing factors, the commercialization of fuel cell vehicles may occur earlier than in the above-mentioned expected year" [19]. More recently, Hyundai has announced that a production version of a fuel cell vehicle will go on sale in 2012 [16].

- General Motors' new fuel cell stack uses nearly two thirds less platinum (30 grams compared to 80 grams) than the stack in the current generation of Equinox vehicles. GM believes it can achieve platinum loadings of 10 
grams, equivalent to today's auto catalytic converters, by 2020 .

- Japanese automakers announced at the 2010 Fuel Cell Expo in Tokyo a program designed to deploy 2 million FCEVs in Japan by 2025, at which point the industry estimates FCEVs would be fully competitive.

Significant challenges remain, however, before the anticipated cost reductions are achieved.

There have been a number of recent evaluations of battery cost as well, generally focusing on lithium-ion chemistry as the most attractive candidate for commercialization. Studies or published estimates include:

- The 2007 report of the ARB Independent Expert Panel [10],

- The 2009 ARB staff report [2] and Technical Support Document [1],

- Comments by Advanced Automotive Batteries on the 2009 ARB staff report [3],

- An MIT study" estimating the "built out cost" of fuel cell and battery vehicles,

- Reports by the Boston Consulting Group [4], Deutsche Bank [5, 6], Pike Research [9], the Rocky Mountain Institute [13] and the Electrification Coalition [7],

- The National Research Council [15] study of PHEVs for the Department of Energy,

- Department of Energy cost projections provided in its summary of Recovery Act investments [14], and

- A TIAX PHEV battery cost assessment performed for the Department of Energy [12].

A review of these studies and reports reveals that the estimates of current costs vary considerably, as do the cost reduction trajectories.

There have been a number of studies of the commercialization potential and possible deployment trajectories for advanced vehicles. Although such studies are highly uncertain, they can provide some insight into future production volumes and hence the likelihood of achieving volume-based cost reductions.

Several manufacturers have stated their own targets for future deployment. Carlos Ghosn, CEO of Renault and Nissan, is on record as predicting that by $2020 \mathrm{EVs}$ will account for 10 percent of sales [18]. VW has announced a goal of having 3 percent of sales in 2018 be EVs [20]. Along the same lines, a number of fuel cell manufacturers have stated their expectation for placements in the hundreds of thousands beginning in 2015, and their intent to market a commercial FCEV beginning in 2015 in Japan, Korea and Europe.

In the final analysis, however, it is important to maintain a customer perspective-what attractive attributes does the

${ }^{6)}$ MIT, op.cit. vehicle have for the purchaser? Unless the consumer sees the vehicle as equivalent or superior to a conventional vehicle, it will be difficult to hit aggressive deployment rates.

\section{Overall conclusions: the prospects of ZEVS}

Plug in Hybrid Electric Vehicles (PHEVs) with modest energy storage capacity will be derived from HEVs and will likely proliferate rapidly, stimulating further development and cost reduction of energy batteries and leading to commercially viable PHEVs and, in the longer term, Full Performance Battery Electric Vehicles (FPBEVs). While PHEVs will continue to grow rapidly, as they have no functional limitations, FPBEVs will grow more slowly due to customer acceptance of limited range and long recharge time. Neighborhood Electric Vehicles (NEVs) are commercially viable now and will continue to grow, but will grow slowly due to limited functionality. City Electric Vehicles (CEVs) will become commercially viable in Japan and Europe in the not too distant future due to lower hurdles for BEVs to overcome. CEVs may be offered in the U.S. as energy batteries continue to mature, but growth will be slow due to functional limitations of BEVs in general, and the specific limitations of CEVs, especially urban freeway driving. The intense effort on FCEVs will result in technically capable vehicles by the 2015 to 2020 time frame, but successful commercialization is dependent on meeting challenging cost goals and the availability of an adequate hydrogen infrastructure. If these challenges are met, FCEVs will likely grow rapidly.

At this time, it is difficult to predict very significant market penetration of full performance BEVs or Fuel Cell

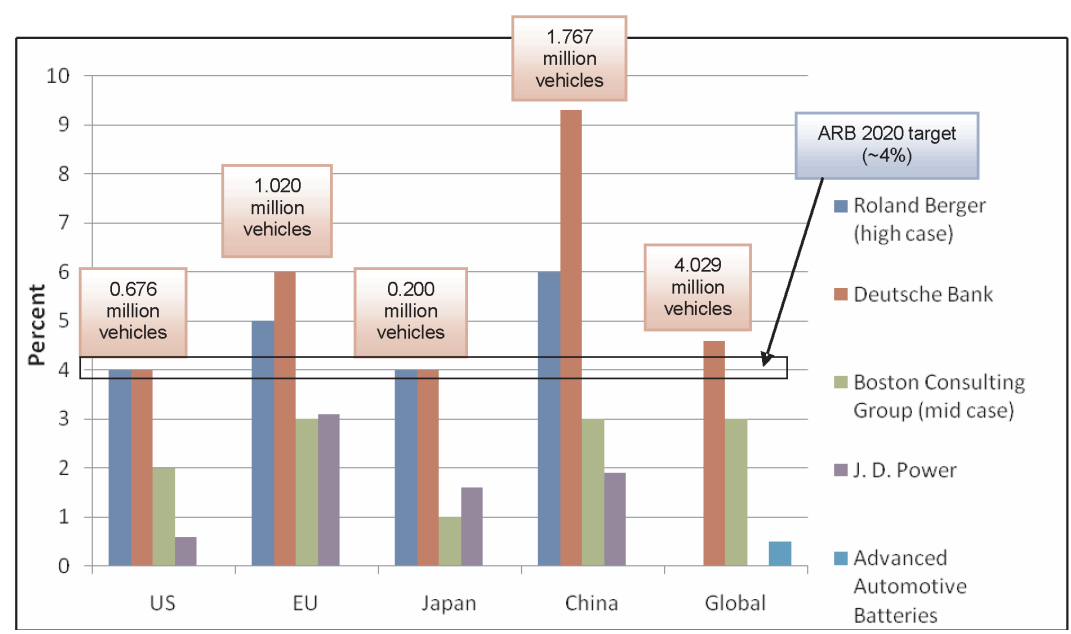

Red box contains vehicle quantities based on Deutsche Bank estimates

vehicles in the next decade on a global scale. In the decade following 2020, greater penetration is possible but will require additional breakthroughs that are hard to predict at this time. In spite of the difficulty, several estimates have been made as is summarized in the figure below.

\section{Conclusions}

The number of motor vehicles and their miles driven has literally exploded over the past 60 years and the likelihood 
is that this growth will continue for the foreseeable future. While vehicle populations are roughly stabilizing in the highly industrialized OECD countries, they are accelerating in rapidly industrializing highly populous countries. In response to strong and aggressive regulatory programs, especially in the United States, new vehicles being sold in many countries today are much cleaner than in the past. For example, over $95 \%$ of all gasoline sold in the world today is lead free and over $95 \%$ of all new gasoline fueled cars are equipped with a three way catalyst which dramatically lowers $\mathrm{CO}, \mathrm{HC}$ and $\mathrm{NO}_{\mathrm{x}}$ emissions per mile driven. As a result, air quality in urban areas in developed countries has generally improved.

However, even in the developed world, air pollution levels in major cities continue to exceed levels necessary to protect public health. And in the rapidly industrializing countries, pollution in many cities is worsening. Therefore, with regard to urban and regional pollution, two major challenges remain:

Paper reviewed
1. To accelerate the introduction of the state of the art technologies for clean vehicles and fuels in rapidly industrializing countries such as China, India and Brazil and get at least modest controls in places where none currently exist such as in much of Africa and the Middle East, and

2. To phase out or clean up the so-called legacy fleet of existing high polluting vehicles. (California, for example, has embarked on an effort to eliminate every diesel vehicle in the State not equipped with a diesel PM filter either by mandatory retrofit or scrappage).

With regard to climate change the picture is much more bleak and the challenge more daunting. Transportation is already a large contributor to the problem and is the most rapidly growing. Modest programs to reduce fuel consumption or greenhouse gas emissions from light duty vehicles are being phased in and California and the EU have initiated efforts to reduce the carbon content of vehicle fuels. But much more will need to be done with a likely shift to battery electric vehicles fueled by green electrons or fuel cell vehicles fueled by renewable hydrogen in future decades. As efforts to reduce $\mathrm{CO}_{2}$ by 70 or $80 \%$ by 2050 receive high priority, aggressive short-term actions to reduce short lived greenhouse pollutants hold promise.

\section{Bibliography}

[1] Air Resources Board, Attachment A, Status of ZEV Technology Commercialization, (Technical Support Document).

[2] Air Resources Board, White Paper: Summary of Staff's Preliminary Assessment of the Need for Revisions to the Zero Emission Vehicle Regulation, Release Date: November 25, 2009.

[3] Anderman M., Feedback on ARB's Zero-Emission Vehicle Staff Technical Report of 11/25/2009 including Attachment A: Status of EV Technology Commercialization, January 6, 2010, p. 2.

[4] Boston Consulting Group, Batteries for Electric Cars, Challenges, Opportunities and the Outlook to 2020, January 2010.

[5] Deutsche Bank, Vehicle Electrification: More rapid growth; steeper price declines for batteries, March 7, 2010.

[6] Electric Cars: Plugged In 2, A mega-theme gains momentum, Deutsche Bank Securities, 3 November 2009.

[7] Electrification Coalition, Electrification Roadmap, Revolutionizing Transportation and Achieving energy Security, November 2009.

[8] Farrell A., Sperling D, (Project Directors), Arons S., Brandt A., Delucchi M., Eggert A., Farrell A., Haya B., Hughes J., Jenkins B., Jones A., Kammen D., Kaffka S., Knittel C., Lemoine D., Martin E., Melaina M., Ogden J., Plevin R., Sperling D., Turner B., Williams R., Yang C. (Contributors): A Low Carbon Fuel Standard for California, Part 1: Technical Analysis, May 29, 2007.

[9] Gargner J., Wheelock C., Electric Vehicles: 10 Predictions for 2010, Pike Research, 4Q 2009.

[10] Kalhammer F.R., Kopf B.M., Swan D.H., Roan V.P., Walsh M.P., Status and Prospects for Zero Emissions Vehicle Technology, Report of the ARB Independent Expert Panel 2007, Prepared for State of California Air Resources Board, Sacramento, California, April 13, 2007.
[11] Passenger Vehicle $\mathrm{CO}_{2}$ and Fuel Economy Standards: A Global Update", The International Council on Clean Transportation, August, 2008.

[12] PHEV Battery Cost Assessment, 2010 DOE Merit Review, TIAX LLC, June 8, 2010.

[13] Status and Trends in the HEV/PHEV/EV Battery Industry, David Anderson, Rocky Mountain Institute, Summer 2008.

[14] The Recovery Act: Transforming America's Transportation Sector, Batteries and Electric Vehicles (Derived from figures in Department Of Energy), Wednesday, July 14, 2010.

[15] Transitions to Alternative Transportation Technologies - Plug-in Hybrid Electric Vehicles, Committee on Assessment of Resource Needs for Fuel, Cell and Hydrogen Technologies; National Research Council.

[16] www.allcarselectric.com/blog/1048608 report-hyundai-fuelcell-electric-vehicle-coming-in-2012.

[17] www.bloomberg.com/apps/news?pid=20601080\&sid= aI_cyfcmTdIs

[18] www.cnbc.com/id/33907442/Ghosn_s_Bet_10_of_World Will_Drive_EV_s_in_10_Years

[19] www.h2carblog.com/wp-content/uploads/2009/10/Letter-ofUnderstanding.pdf

[20] www.treehugger.com/files/2010/03/volkswagen-plans-sell300000-electric-cars-year-2018.php

Michael Walsh - International Consultant, Board Chairman, International Council on Clean Transportation, USA.

Michael Walsh - międzynarodowy konsultant przewodniczacy ICCT, USA.

e-mail:mpwalsh@igc.org 